\title{
Leaf Boron and Potassium and Nut Weight in Coconut (Cocos nucifera L.) as Affected by their Individual and Combined Applications in Terai Region of West Bengal
}

\author{
N. Sathi Babu' ${ }^{*}$, P. S. Medda ${ }^{2}$, Himadri Bhattacharjee ${ }^{2}$, A. Kumar Sinha ${ }^{3}$ and A. Ghosh \\ ${ }^{1}$ Krishi Vigyana Kendra, Kondempudi, Visakhapatnam District, Acharya N.G Ranga \\ Agricultural University, Andhra Pradesh, India \\ ${ }^{2}$ Departments of Plantation Crops and Processing, ${ }^{3}$ Department of Soil Science \& \\ Agricultural Chemistry, ${ }^{4}$ Department of Agricultural Statistics, Uttar Banga Krishi \\ Viswavidyalaya, Cooch Behar, West Bengal, India \\ *Corresponding author
}

A major limiting factor in harnessing the potential nut weight in coconut (Cocos nucifera L.) in terai region of West Bengal is low leaf potassium and boron contents. For ascertaining the same in quantitative terms, an experiment was undertaken to evaluate the

Keywords

Borax, Muriate of Potash (MoP), Interaction effect, Nut weight

\section{Article Info}

Accepted:

10 January 2021

Available Online:

10 February 2021 effects of potassium applied as muriate of potash @ 900, 1200 and $1500 \mathrm{~g}$ and boron as borax@ 25, 50, and $100 \mathrm{~g} / \mathrm{palm} /$ year on leaf boron and potassium contents and nut weight in coconut during 2014-15 and 2015-16. The index leaf (14 ${ }^{\text {th }}$ frond) was used for determining the nutrients at 6 and 12 months after application. Application of the nutrients resulted in a significant increase in the respective nutrient content of the leaves. The combined application of the nutrients at the intermediate level (1200 g MoP with $50 \mathrm{~g}$ borax) recorded the maximum nut weight $(1948.50 \mathrm{~g})$ at 7 month age of nuts with $1.97 \%$ potassium and $24.52 \mathrm{mg} / \mathrm{kg}$ boron content of the leaves. The increase in nut weight was observed between from $6^{\text {th }}$ to $7^{\text {th }}$ months and thereafter, decreased progressively up to $12^{\text {th }}$ months Further increase in the rate of application caused a decline in nut weight, despite an increase in the nutrient contents of the leaves. The combined application of the nutrients beyond the intermediate level also revealed the same trend, implying a negative interaction effect. Nut weight showed a positive correlation with increased leaf potassium and boron content only upto a certain level of application. Beyond this 'greater than the optimum' level, the nutrients resulted in a negative effect on nut weight.

\section{Introduction}

Terai region of West Bengal witnessed a sharp rise in the acreage under coconut (Cocos nucifera L.) in the last couple of years. The crop in the region is grown in homestead gardens and as a plantation crop too, and appears to be very promising in economic returns. The nut weight and yield is however, very poor - in terms of both quality 
and quantity - due mainly to lack of nutrient management and irrational application of fertilizers. Coarse texture of the soils, high rainfall of the region, low soil $\mathrm{pH}$, and nutrient removal by leaching and the crop contribute to multiple nutrient deficiencies. Among the deficient plant nutrients, potassium (K) and boron (B) have proved to be more significant than others. The two nutrients contribute to increased nut size, nut weight, and softness of the biomass of the copra, improved kernel development, faster translocation of sugars and starch from leaves to nuts, and higher sweetness of the coconut water. In addition, high leaf $\mathrm{K}$ content helps regulate the plant's metabolism, opening and closure of the stomata required for water economy, activation of many crucial enzymes, maintenance of cation-anion balance in the cells, and control the transport of the metabolites required for cell division. However, there has so far been no study on the effects of B and $\mathrm{K}$ on such aspects in such soils. A study was therefore, undertaken to evaluate the effects of $\mathrm{B}$ and $\mathrm{K}$ applied alone or in combination on the concentrations of the nutrients in the leaves and relates these concentrations to the nut weight in coconut grown in the terai region of West Bengal.

\section{Materials and Methods}

The experiment was conducted during 201415 and 2015-16 at the Instructional Plots of the Department of Plantation Crops and Processing, Uttar Banga Krishi Viswavidyalaya, West Bengal. The experimental field is located at $43 \mathrm{~m}$ above mean sea level at $26^{\circ} 19^{\prime} 86^{\prime \prime} \mathrm{N}$ latitude and $89^{\circ} 23^{\prime} 53^{\prime \prime}$ E longitude. Physico-chemical properties of the soil analysed by standard methods were: texture- sandy loam, $\mathrm{pH}-5.45$ (Jackson, 1973), electrical conductivity - 0.06 $\mathrm{dsm}^{-1}$ (Jackson, 1973), organic carbon 0.93\% (Walkley and Black, 1934), available N - 159. $32 \mathrm{~kg} / \mathrm{ha}$ (Subbiah and Asija, 1956), available $\mathrm{P}$ - $23.15 \mathrm{~kg} / \mathrm{ha}$ (Bray and Kurtz, 1945), available $\mathrm{K}-87.15 \mathrm{~kg} / \mathrm{ha}$ (Jackson, 1967), and available B $-0.59 \mathrm{mg} / \mathrm{kg}$ (Hot water extractable as proposed by Berger and Truog, 1939).

The experiment was laid out in Factorial Randomised Block Design with 9 treatments, with three different levels of potassium viz. $\mathrm{K}_{1}, \mathrm{~K}_{2}$, and $\mathrm{K}_{3} @ 900,1200$ and $1500 \mathrm{~g}$ of $\mathrm{K}_{2} \mathrm{O}$ (as MoP, $60 \% \mathrm{~K}_{2} \mathrm{O}$ ) and three levels of boron viz. $\mathrm{B}_{1}, \mathrm{~B}_{2}$, and $\mathrm{B}_{3} @ 25,50$, and $100 \mathrm{~g}$ (as borax, $10.5 \% \mathrm{~B}$ ) per palm per year at a spacing of $7.5 \times 7.5 \mathrm{~m}$ in 9 years old East Coast Tall. Each treatment was replicated 4 times The nine different treatment combinations were as follows: $\mathrm{T}_{1}: \mathrm{B}_{1} \mathrm{~K}_{1}: 25 \mathrm{~g}$ borax/palm + $900 \mathrm{~g} \mathrm{~K}_{2} \mathrm{O} /$ palm, $\mathrm{T}_{2}: \mathrm{B}_{1} \mathrm{~K}_{2:} 50 \mathrm{~g}$ borax/palm + $1200 \mathrm{~g} \mathrm{~K}_{2} \mathrm{O} /$ palm, $\mathrm{T}_{3}: \mathrm{B}_{1} \mathrm{~K}_{3}: 25 \mathrm{~g}$ borax/palm + $1500 \mathrm{~g} \mathrm{~K}_{2} \mathrm{O} /$ palm, $\mathrm{T}_{4}: \mathrm{B}_{2} \mathrm{~K}_{1:}: 50 \mathrm{~g}$ borax/palm + $900 \mathrm{~g} \mathrm{~K}_{2} \mathrm{O} /$ palm, $\mathrm{T}_{5}: \mathrm{B}_{2} \mathrm{~K}_{2:} 50 \mathrm{~g}$ borax /palm + $1200 \mathrm{~g} \mathrm{~K}_{2} \mathrm{O} /$ palm, $\mathrm{T}_{6}: \mathrm{B}_{2} \mathrm{~K}_{3} 50$ g borax/palm $+1500 \mathrm{~g} \mathrm{~K}_{2} \mathrm{O} /$ palm, $\mathrm{T}_{7}: \mathrm{B}_{3} \mathrm{~K}_{1}$ : $100 \mathrm{~g}$ borax/palm $+900 \mathrm{~g} \mathrm{~K} 2 \mathrm{O} /$ palm, $\mathrm{T}_{8}$ : $\mathrm{B}_{3} \mathrm{~K}_{2:} 100 \mathrm{~g}$ borax/palm $+1200 \mathrm{~g} \mathrm{~K}_{2} \mathrm{O} /$ palm and $\mathrm{T}_{9}: \mathrm{B}_{3} \mathrm{~K}_{3:} 100 \mathrm{~g}$ borax $/$ palm $+1500 \mathrm{~g}$ $\mathrm{K}_{2} \mathrm{O} /$ palm. All the palms were fertilized uniformly with $500 \mathrm{~g} \mathrm{~N}$ (as urea, 46\% N) and $320 \mathrm{~g}$ of $\mathrm{P}_{2} \mathrm{O}_{5}$ (as SSP, $16 \% \mathrm{P}_{2} \mathrm{O}_{5}$ ) per palm along with the required amount of boron and potassium as per the treatment combinations. Half of the doses of the nutrients were applied in May, 2014 as pre-monsoon application, while the remaining half was applied in September, 2014 as post-monsoon application. The same fertilizer schedule was repeated for the year 2015. The fertilizers were applied at $180 \mathrm{~cm}$ away from the base of the palms ( De Silva, 1968).The initial soil samples at 0-30 cm depth were collected at random before commencement of the study; thereafter, sampling was done at 6 month intervals at a the same depth at sites $1.8 \mathrm{~m}$ away from the trunk of the palm. For the determination of boron and potassium content of leaf, the leaf samples were collected from 
the index leaf i.e. $14^{\text {th }}$ fronds for analysis before application of the fertilizers and subsequently at 6 and 12 months after application. The $14^{\text {th }}$ fronds were chosen as the index leaf for analysis of as suggested by Reuter and Robinson (1997). The leaf samples were digested by tri-acid mixture and the acid digests as such or after proper dilution were analysed for their potassium content by flame photometry as described by Muhr et al., (1965). For determining boron, the digests were analysed by the method suggested by Berger and Truog (1939). The coconut nut weight were recorded at intervals of $6^{\text {th }}, 7^{\text {th }}, 8^{\text {th }}, 9^{\text {th }}$ and $12^{\text {th }}$ month age of nuts during 2014-15 and 2015-16.

\section{Results and Discussion}

\section{Effect of boron and potassium application and their interactions on leaf $K$ content}

The results pertaining to the effect of application of boron at different levels on leaf $\mathrm{K}$ content are presented in Table 1 and showed that there was a little variation in leaf $\mathrm{K}$ content between the two consecutive years of study. However, with increase in the level of boron application from $B_{1}$ to $B_{2}$, there was significant increase in leaf $\mathrm{K}$ content. Increased $\mathrm{K}$ uptake at an optimum level of soil boron has been reported by Samet et al., (2015) in pepper. With further increase in boron application rate, the leaf $\mathrm{K}$ content decreased substantially. This decrease was might be due to the toxic concentration of boron in the soil at $\mathrm{B}_{3}$ level of boron application. Mengel and Kirkby (2001) reported that excess supply of boron in growth medium reduced uptake of $\mathrm{K}$ and vice versa.

The results in relation to the effect of potassium applications at different graded levels on the leaf $\mathrm{K}$ content are also depicted in Table 1 and showed that there was high consistency in leaf $\mathrm{K}$ content between the results of the two years. In any case, with increase in potassium supply, the nutrient continues to be increasingly absorbed as seen in increased leaf $\mathrm{K}$ content. Venkitaswamy et al., (2011) also reported results in similar lines.

The results revealed that the leaf $\mathrm{K}$ content was the highest in $\mathrm{B}_{1} \mathrm{~K}_{3}$ treatment followed by $\mathrm{B}_{2} \mathrm{~K}_{3}$ and $\mathrm{B}_{2} \mathrm{~K}_{2}$ treatments and it was lowest in $\mathrm{B}_{3} \mathrm{~K}_{1}$ followed by $\mathrm{B}_{1} \mathrm{~K}_{1}$ and $\mathrm{B}_{3} \mathrm{~K}_{3}$ (Table 1 ). Boron-potassium interactions at the applied levels and combinations caused the differences in the leaf $\mathrm{K}$ content. The results of the study suggested that, there was synergistic interaction effect between $\mathrm{K}$ and $\mathrm{B}$ in the case of $\mathrm{B}_{1} \mathrm{~K}_{3}, \mathrm{~B}_{2} \mathrm{~K}_{3}$, and $\mathrm{B}_{2} \mathrm{~K}_{2}$ treatments resulting in increased $\mathrm{K}$ uptake. The interaction between these two nutrients was antagonistic also in $\mathrm{B}_{3} \mathrm{~K}_{1}$ and $\mathrm{B}_{3} \mathrm{~K}_{3}$ combinations. Mengel and Kirkby (2001) observed that $\mathrm{B}$ and $\mathrm{K}$ interaction was negative with an excess supply of boron.

All the levels of boron and potassium and their interaction effects pertaining to leaf $\mathrm{K}$ content were showed progressively decreasing trend from 6 month to 12 months after soil application of boron and potassium.

Effect of application of boron and potassium and their interactions on leaf $B$ content

The results pertaining to the effect of boron application at different rates on leaf B content are presented in Table 1. A careful approval of results showed a negligible variation in leaf B content between the results of the two years. With increase in the level of boron application, there was significant and proportionate increase in leaf boron content. B content in leaf increased. Similar results have been reported by Moura et al., (2013) and Nistane et al., (2011) in coconut. 
Table.1 Effect of boron and potassium application and their interaction on potassium and boron content of leaves

\begin{tabular}{|c|c|c|c|c|c|c|c|c|c|c|c|c|}
\hline \multirow{3}{*}{ Levels of Boron } & \multicolumn{6}{|c|}{ Leaf $K$ content $(\%)$} & \multicolumn{6}{|c|}{ Leaf $B$ content $(\mathrm{mg} / \mathrm{kg})$} \\
\hline & \multicolumn{3}{|c|}{6 months (December) } & \multicolumn{3}{|c|}{12 months (June) } & \multicolumn{3}{|c|}{6 months (December) } & \multicolumn{3}{|c|}{12 months (June) } \\
\hline & 2014-15 & 2015-16 & Pooled & 2014-15 & 2015-16 & Pooled & 2014-15 & 2015-16 & Pooled & 2014-15 & 2015-16 & Pooled \\
\hline $\mathbf{B}_{1}$ & 1.72 & 1.73 & 1.73 & 1.03 & 1.03 & 1.03 & 14.09 & 14.52 & 14.30 & 8.932 & 9.034 & 8.983 \\
\hline $\mathbf{B}_{2}$ & 1.82 & 1.84 & 1.83 & 1.06 & 1.05 & 1.06 & 22.58 & 22.67 & 22.62 & 11.79 & 12.05 & 11.92 \\
\hline $\mathbf{B}_{3}$ & 1.31 & 1.31 & 1.31 & 0.86 & 0.86 & 0.86 & 30.79 & 31.27 & 31.03 & 14.77 & 14.61 & 14.69 \\
\hline $\mathrm{SE}(\mathbf{m}) \pm$ & 0.01 & 0.01 & 0.01 & 0.01 & 0.01 & 0.01 & 0.16 & 0.19 & 0.15 & 0.25 & 0.25 & 0.22 \\
\hline LSD $(P=0.05)$ & 0.02 & 0.01 & 0.01 & 0.02 & 0.03 & 0.02 & 0.48 & 0.56 & 0.43 & 0.72 & 0.73 & 0.63 \\
\hline \multirow{2}{*}{$\begin{array}{c}\text { Levels of } \\
\text { Potassium }\end{array}$} & \multicolumn{3}{|c|}{6 months (December) } & \multicolumn{3}{|c|}{12 months (June) } & \multicolumn{3}{|c|}{6 months (December) } & \multicolumn{3}{|c|}{12 months (June) } \\
\hline & 2014-15 & 2015-16 & Pooled & 2014-15 & 2015-16 & Pooled & 2014-15 & 2015-16 & Pooled & 2014-15 & 2015-16 & Pooled \\
\hline $\mathbf{K}_{1}$ & 1.12 & 1.12 & 1.12 & 0.86 & 0.85 & 0.86 & 23.22 & 23.63 & 23.42 & 12.25 & 12.34 & 12.29 \\
\hline $\mathbf{K}_{2}$ & 1.74 & 1.75 & 1.75 & 1.03 & 1.03 & 1.03 & 23.24 & 23.78 & 23.51 & 12.39 & 12.37 & 12.38 \\
\hline $\mathbf{K}_{3}$ & 1.99 & 2.00 & 2.00 & 1.06 & 1.05 & 1.06 & 21.00 & 21.05 & 21.02 & 10.84 & 10.98 & 10.91 \\
\hline $\mathrm{SE}(\mathrm{m}) \pm$ & 0.01 & 0.00 & 0.01 & 0.01 & 0.01 & 0.01 & 0.16 & 0.19 & 0.15 & 0.25 & 0.25 & 0.22 \\
\hline LSD $(P=0.05)$ & 0.02 & 0.01 & 0.01 & 0.02 & 0.03 & 0.02 & 0.48 & 0.56 & 0.43 & 0.72 & 0.73 & 0.63 \\
\hline \multirow{2}{*}{$\begin{array}{c}\text { Treatment } \\
\text { combinations }\end{array}$} & \multicolumn{3}{|c|}{6 months (December) } & \multicolumn{3}{|c|}{12 months (June) } & \multicolumn{3}{|c|}{6 months (December) } & \multicolumn{3}{|c|}{12 months (June) } \\
\hline & 2014-15 & 2015-16 & Pooled & 2014-15 & 2015-16 & Pooled & 2014-15 & 2015-16 & Pooled & 2014-15 & 2015-16 & Pooled \\
\hline $\mathbf{B}_{1} \mathbf{K}_{1}$ & 1.10 & 1.10 & 1.10 & 0.83 & 0.83 & 0.83 & 14.22 & 14.73 & 14.47 & 9.60 & 9.48 & 9.54 \\
\hline $\mathbf{B}_{1} \mathbf{K}_{2}$ & 1.75 & 1.75 & 1.75 & 1.04 & 1.03 & 1.03 & 15.73 & 15.98 & 15.85 & 9.98 & 10.26 & 10.12 \\
\hline $\mathbf{B}_{\mathrm{I}} \mathbf{K}_{3}$ & 2.32 & 2.33 & 2.33 & 1.22 & 1.22 & 1.22 & 12.31 & 12.85 & 12.58 & 7.22 & 7.36 & 7.29 \\
\hline $\mathbf{B}_{2} \mathbf{K}_{1}$ & 1.29 & 1.30 & 1.29 & 0.99 & 0.98 & 0.98 & 22.08 & 22.32 & 22.20 & 11.39 & 11.76 & 11.58 \\
\hline $\mathbf{B}_{2} \mathbf{K}_{2}$ & 1.96 & 1.97 & 1.97 & 1.10 & 1.10 & 1.10 & 25.00 & 24.05 & 24.52 & 13.05 & 13.31 & 13.18 \\
\hline $\mathbf{B}_{\mathbf{2}} \mathbf{K}_{\mathbf{3}}$ & 2.21 & 2.24 & 2.23 & 1.10 & 1.08 & 1.09 & 20.67 & 20.05 & 20.36 & 10.91 & 11.06 & 10.99 \\
\hline $\mathbf{B}_{3} \mathbf{K}_{1}$ & 0.97 & 0.97 & 0.97 & 0.75 & 0.75 & 0.75 & 33.42 & 34.29 & 33.86 & 16.18 & 15.87 & 16.02 \\
\hline $\mathbf{B}_{\mathbf{3}} \mathbf{K}_{\mathbf{2}}$ & 1.52 & 1.53 & 1.52 & 0.96 & 0.96 & 0.96 & 28.93 & 29.28 & 29.11 & 13.72 & 13.45 & 13.58 \\
\hline $\mathbf{B}_{3} K_{3}$ & 1.43 & 1.44 & 1.43 & 0.85 & 0.86 & 0.86 & 30.02 & 30.24 & 30.13 & 14.40 & 14.52 & 14.46 \\
\hline $\mathrm{SE}(\mathrm{m}) \pm$ & 0.01 & 0.01 & 0.01 & 0.01 & 0.02 & 0.01 & 0.28 & 0.33 & 0.25 & 0.43 & 0.43 & 0.37 \\
\hline LSD $(P=0.05)$ & 0.04 & 0.02 & 0.02 & 0.03 & 0.04 & 0.03 & 0.84 & 0.97 & 0.74 & 1.25 & 1.26 & 1.09 \\
\hline
\end{tabular}


Table.2 Effect of application of boron and potassium and their interaction on nut weight $(\mathrm{g})$ at $6^{\text {th }}, 7^{\text {th }}, 8^{\text {th }}, 9^{\text {th }}$ and $12^{\text {th }}$ months age of nuts

\begin{tabular}{|c|c|c|c|c|c|c|c|c|c|c|c|c|c|c|c|}
\hline \multirow[b]{2}{*}{$\begin{array}{l}\text { Levels of } \\
\text { Boron }\end{array}$} & \multicolumn{3}{|c|}{$6^{\text {th }}$ month } & \multicolumn{3}{|c|}{$7^{\text {th }}$ month } & \multicolumn{3}{|c|}{$8^{\text {th }}$ month } & \multicolumn{3}{|c|}{$9^{\text {th }}$ month } & \multicolumn{3}{|c|}{$12^{\text {th }}$ month } \\
\hline & 2014-15 & 2015-16 & Pooled & 2014-15 & 2015-16 & Pooled & 2014-15 & 2015-16 & Pooled & 2014-15 & 2015-16 & Pooled & 2014-15 & $2015-16$ & Pooled \\
\hline $\mathbf{B}_{1}$ & 1717.42 & 1722.75 & 1720.08 & 1801.75 & 1807.92 & 1804.83 & 1726.00 & 1732.42 & 1729.21 & 1624.25 & 1627.75 & 1626.00 & 1189.00 & 1182.42 & 1185.71 \\
\hline $\mathbf{B}_{2}$ & 1772.50 & 1778.00 & 1775.25 & 1858.25 & 1863.67 & 1860.96 & 1777.25 & 1784.42 & 1780.83 & 1661.92 & 1670.17 & 1666.04 & 1272.00 & 1261.25 & 1266.63 \\
\hline $\mathbf{B}_{\mathbf{3}}$ & 1524.17 & 1531.92 & 1528.04 & 1564.83 & 1570.67 & 1567.46 & 1521.58 & 1526.42 & 1524.00 & 1451.42 & 1456.83 & 1454.13 & 1003.92 & 999.92 & 1001.92 \\
\hline $\mathrm{SE}(\mathrm{m}) \pm$ & 6.06 & 6.86 & 6.40 & 5.66 & 5.36 & 5.47 & 3.65 & 4.73 & 4.07 & 4.54 & 4.33 & 4.34 & 6.20 & 6.08 & 5.90 \\
\hline $\begin{array}{c}\text { LSD } \\
(\mathbf{P}=\mathbf{0 . 0 5})\end{array}$ & 17.79 & 20.13 & 18.80 & 16.61 & 15.75 & 16.07 & 10.72 & 13.89 & 11.95 & 13.33 & 12.70 & 12.73 & 18.20 & 17.84 & 17.32 \\
\hline \multirow[b]{2}{*}{$\begin{array}{l}\text { Levels of } \\
\text { Potassiu } \\
\text { m }\end{array}$} & \multicolumn{3}{|c|}{$6^{\text {th }}$ month } & \multicolumn{3}{|c|}{$7^{\text {th }}$ month } & \multicolumn{3}{|c|}{$8^{\text {th }}$ month } & \multicolumn{3}{|c|}{$9^{\text {th }}$ month } & \multicolumn{3}{|c|}{$12^{\text {th }}$ month } \\
\hline & 2014-15 & 2015-16 & Pooled & 2014-15 & 2015-16 & Pooled & 2014-15 & $2015-16$ & Pooled & 2014-15 & 2015-16 & Pooled & 2014-15 & 2015-16 & Pooled \\
\hline $\mathbf{K}_{1}$ & 1611.67 & 1619.75 & 1615.71 & 1663.92 & 1669.83 & 1666.88 & 1617.75 & 1624.33 & 1621.04 & 1522.08 & 1526.92 & 1524.50 & 1075.17 & 1075.17 & 1075.17 \\
\hline $\mathbf{K}_{2}$ & 1739.75 & 1745.33 & 1742.54 & 1823.08 & 1827.92 & 1825.50 & 1746.58 & 1752.67 & 1749.63 & 1637.75 & 1643.33 & 1640.54 & 1220.08 & 1213.08 & 1216.58 \\
\hline $\mathbf{K}_{3}$ & 1662.67 & 1667.58 & 1665.13 & 1737.83 & 1744.50 & 1740.88 & 1660.50 & 1666.25 & 1663.38 & 1577.75 & 1584.50 & 1581.13 & 1169.67 & 1155.33 & 1162.50 \\
\hline $\mathrm{SE}(\mathrm{m}) \pm$ & 6.06 & 6.86 & 6.40 & 5.66 & 5.36 & 5.47 & 3.65 & 4.73 & 4.07 & 4.54 & 4.33 & 4.34 & 6.20 & 6.08 & 5.90 \\
\hline $\begin{array}{c}\text { LSD } \\
(\mathbf{P}=0.05)\end{array}$ & 17.79 & 20.13 & 18.80 & 16.61 & 15.75 & 16.07 & 10.72 & 13.89 & 11.95 & 13.33 & 12.70 & 12.73 & 18.20 & 17.84 & 17.32 \\
\hline
\end{tabular}

\begin{tabular}{|c|c|c|c|c|c|c|c|c|c|c|c|c|c|c|c|}
\hline \multicolumn{16}{|c|}{ Interaction effect of application of boron and potassium on nut weight $(\mathrm{g})$ at $6^{\text {th }}, 7^{\text {th }}, 8^{\text {th }}, 9^{\text {th }}$ and $12^{\text {th }}$ months age of nuts } \\
\hline \multirow[b]{2}{*}{ Treatments } & \multicolumn{3}{|c|}{$6^{\text {th }}$ month } & \multicolumn{3}{|c|}{$7^{\text {th }}$ month } & \multicolumn{3}{|c|}{$8^{\text {th }}$ month } & \multicolumn{3}{|c|}{$9^{\text {th }}$ month } & \multicolumn{3}{|c|}{$12^{\text {th }}$ month } \\
\hline & 2014-15 & 2015-16 & Pooled & 2014-15 & 2015-16 & Pooled & 2014-15 & 2015-16 & Pooled & 2014-15 & 2015-16 & Pooled & 2014-15 & 2015-16 & Pooled \\
\hline $\mathbf{B}_{1} \mathbf{K}_{1}$ & 1669.25 & 1673.25 & 1671.25 & 1730.00 & 1736.75 & 1733.38 & 1686.25 & 1692.50 & 1689.38 & 1588.00 & 1591.00 & 1589.50 & 1123.25 & 1117.00 & 1120.13 \\
\hline $\mathbf{B}_{1} \mathbf{K}_{2}$ & 1774.50 & 1779.00 & 1776.75 & 1866.00 & 1871.25 & 1868.63 & 1780.50 & 1789.00 & 1784.75 & 1665.75 & 1670.50 & 1668.13 & 1256.50 & 1249.50 & 1253.00 \\
\hline $\mathbf{B}_{\mathbf{I}} \mathrm{K}_{\mathbf{3}}$ & 1708.50 & 1716.00 & 1712.25 & 1809.25 & 1815.75 & 1812.50 & 1711.25 & 1715.75 & 1713.50 & 1619.00 & 1621.75 & 1620.38 & 1187.25 & 1180.75 & 1184.00 \\
\hline $\mathbf{B}_{2} \mathbf{K}_{1}$ & 1692.00 & 1700.50 & 1696.25 & 1756.25 & 1761.25 & 1758.75 & 1705.75 & 1712.75 & 1709.25 & 1600.50 & 1607.25 & 1603.88 & 1150.50 & 1144.75 & 1147.63 \\
\hline $\mathbf{B}_{2} K_{2}$ & 1866.50 & 1870.75 & 1868.63 & 1946.25 & 1950.75 & 1948.50 & 1848.75 & 1855.50 & 1852.13 & 1716.25 & 1723.25 & 1719.75 & 1352.00 & 1345.25 & 1348.63 \\
\hline $\mathbf{B}_{2} \mathbf{K}_{3}$ & 1759.00 & 1762.75 & 1760.88 & 1872.25 & 1879.00 & 1875.63 & 1777.25 & 1785.00 & 1781.13 & 1669.00 & 1680.00 & 1674.50 & 1313.50 & 1293.75 & 1303.63 \\
\hline $\mathbf{B}_{3} \mathbf{K}_{2}$ & 1578.25 & 1586.25 & 1582.25 & 1657.00 & 1661.75 & 1659.38 & 1610.50 & 1613.50 & 1612.00 & 1531.25 & 1536.25 & 1533.75 & 1051.75 & 1044.50 & 1048.13 \\
\hline $\mathbf{B}_{3} \mathbf{K}_{3}$ & 1520.50 & 1524.00 & 1522.25 & 1532.00 & 1538.75 & 1534.50 & 1493.00 & 1498.00 & 1495.50 & 1445.25 & 1451.75 & 1448.50 & 1008.25 & 991.50 & 999.88 \\
\hline $\mathrm{SE}(\mathrm{m}) \pm$ & 10.49 & 11.87 & 11.09 & 9.80 & 9.29 & 9.48 & 6.32 & 8.20 & 7.05 & 7.87 & 7.49 & 7.51 & 10.73 & 10.53 & 10.22 \\
\hline LSD $(P=0.05)$ & 30.81 & 34.87 & 32.56 & 28.78 & 27.27 & 27.83 & 18.56 & 24.06 & 20.69 & 23.09 & 22.01 & 22.05 & 31.52 & 30.91 & 30.00 \\
\hline
\end{tabular}


Fig.1 Effect of born on nut weight $(\mathrm{g})$ at $6^{\text {th }}, 7^{\text {th }}, 8^{\text {th }}, 9^{\text {th }}$ and $12^{\text {th }}$ months age of nuts

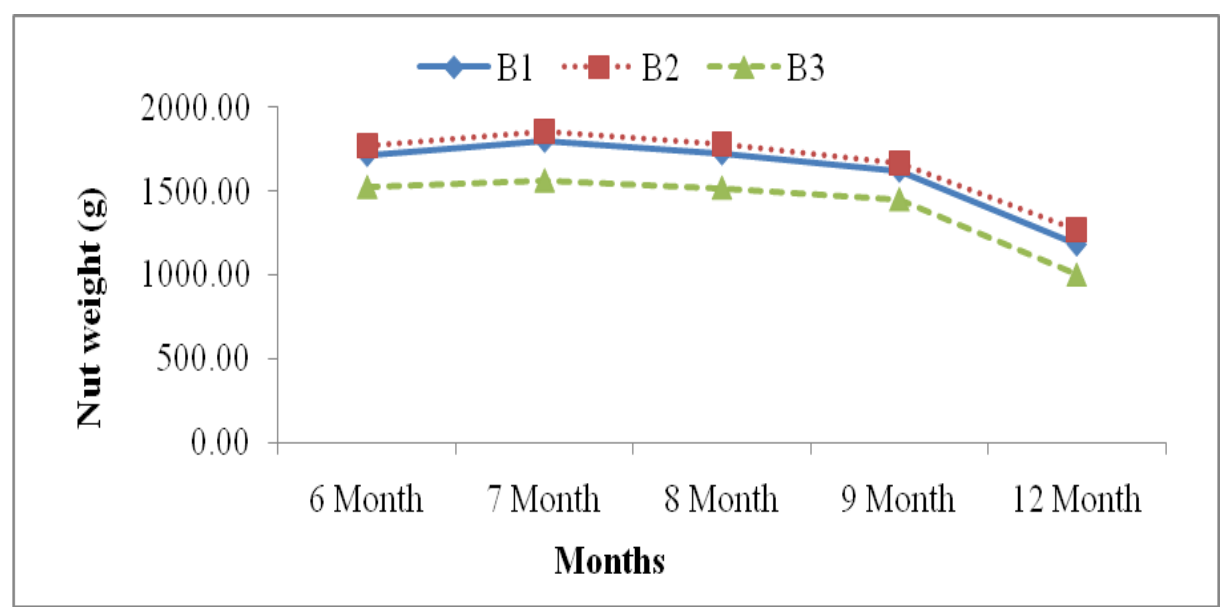

Fig.2 Effect of potassium on nut weight $(\mathrm{g})$ at $6^{\text {th }}, 7^{\text {th }}, 8^{\text {th }}, 9^{\text {th }}$ and $12^{\text {th }}$ months age of nuts

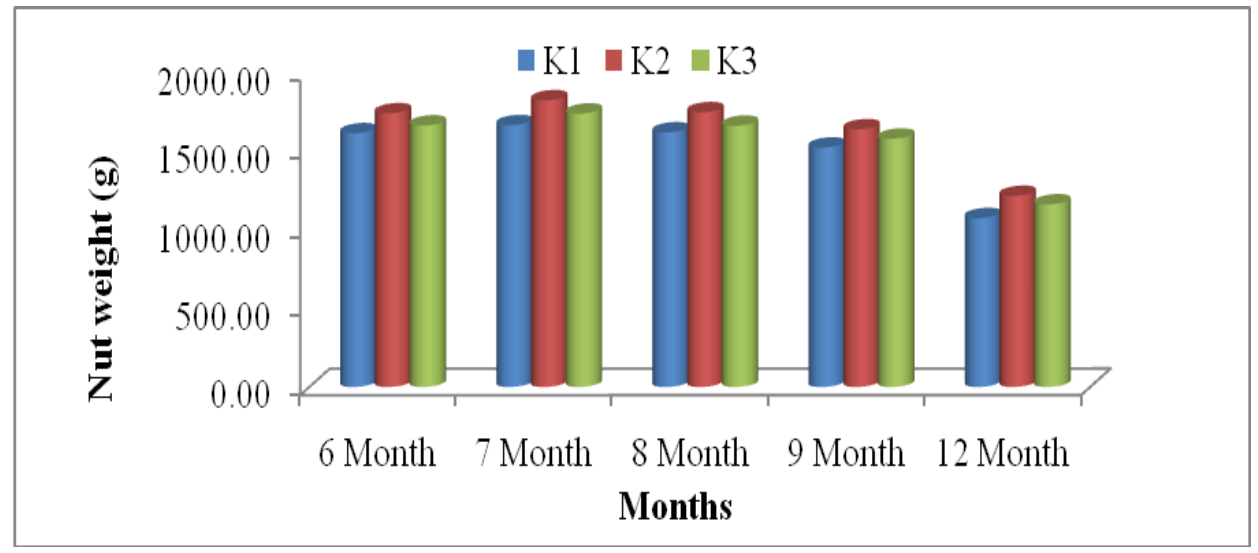

Fig.3 Interaction effect of boron and potassium on nut weight $(\mathrm{g})$ at $6^{\text {th }}, 7^{\text {th }}, 8^{\text {th }}, 9^{\text {th }}$ and $12^{\text {th }}$ months age of nuts

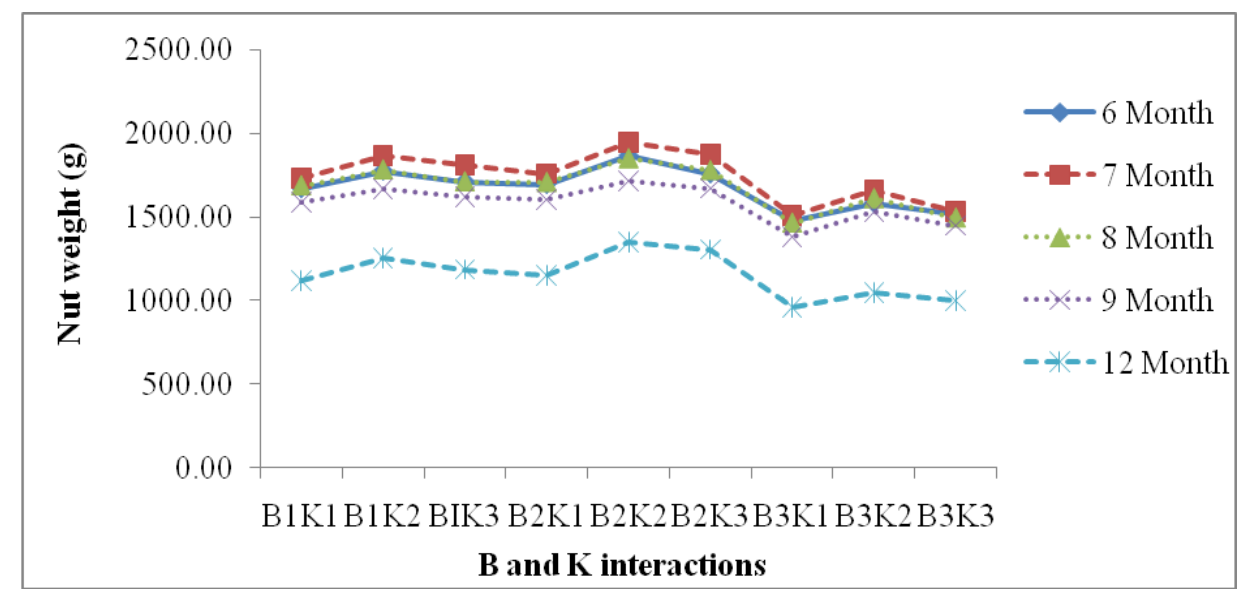


On the other hand, with increase in the level of potassium from $K_{1}$ to $K_{2}$, there was little increase in the leaf boron content from 23.63 to 23.78 in $2015-16$ at 6 months after application and it was statistically at par with each other. With further increase in potassium level, there was sharp decrease in boron content of the leaves from 23.78 to 21.05 in 2015-16 and it was statistically significant. This variation suggests negative interaction between $\mathrm{B}$ and $\mathrm{K}$ at excess levels of available $\mathrm{K}$ due possibly to cation-anion imbalance as has been reported earlier by Samet et al., (2015). The same trend was observed in 2014-15 and also in the case of pooled results for the two years.

A perusal of data presented in Table 1 showed that the leaf $\mathrm{B}$ content was the highest in $\mathrm{B}_{3} \mathrm{~K}_{1}$ treatment followed by $\mathrm{B}_{3} \mathrm{~K}_{3}$ and $\mathrm{B}_{3} \mathrm{~K}_{2}$ treatments. Boron-potassium interactions at the applied rates and combinations might have caused the differences in the leaf $\mathrm{B}$ content. This type of effect may be due to excess application of potassium caused to decrease in leaf B content. The results of the study suggest that as regards to leaf B content, there was synergistic interaction effect between potassium and boron in certain cases and antagonistic interaction in some cases. The results of the study are in agreement with those of present findings confirmed the findings of Ranade-Malvi (2011). Further, it appears that the individual effects of boron and potassium and also their interaction effects pertaining to the leaf boron content had a decreasing trend from 6 to 12 months after soil application of boron and potassium. The continued decrease in leaf boron content may because of the fact that during this period (6 to 12 months), boron might have been utilized in fruit setting, boosts up pollination, seed development, formation of meristimatic tissues, synthesis of cell wall, lignifications maintenances of cell wall structure integrity nitrogen metabolism, and protein biosynthesis. A similar result was also reported by Ahmad et al., (2009).

\section{Effect of boron and potassium application and their interaction on nut weight}

The results with relation to effect of graded levels boron at different rates on nut weight at different month age of nuts are presented in Table 2 and Figure 1. The results showed that in both the years, the nut weight was the highest at $\mathrm{B}_{2}$ level of boron at $6^{\text {th }}, 7^{\text {th }}, 8^{\text {th }}, 9^{\text {th }}$ and $12^{\text {th }}$ month age of nuts after application. With increase in boron level from $\mathrm{B}_{1}$ to $\mathrm{B}_{2}$, there was a substantial increase in nut weight at all the months. With further increase in boron to $\mathrm{B}_{3}$ level, the nut weight was reduced. At $\mathrm{B}_{3}$ level, there must have been boron toxicity causing hindrance in potassium availability and uptake reflected through decreased nut weight. A similar line reports were reported by Nistane et al., (2011). The maximum nut weight was recorded at $\mathrm{B}_{2}$ level of boron at $7^{\text {th }}$ month age of nuts after application as evident from pooled result (1860.96 g). The increase in nut weight was observed between from $6^{\text {th }}$ to $7^{\text {th }}$ months and thereafter, decreased progressively up to $12^{\text {th }}$ months. The low boron availability in the soils may be the reason for decreased nut weight at $\mathrm{B}_{1}$ level. Nut weight increase might be due to involvement in hormonal metabolism, increase cell division and expansion of cell and also known to stimulate rapid mobilization of water and sugars in the nut as suggested by Singh et al., (2012).

Table 2 and Figure 2, revealed that the effect of potassium application at different rates on nut weight. The results elucidate that in both the years, the nut weight was the highest at $\mathrm{K}_{2}$ level of potassium. There was a substantial increase in nut weight when potassium level was increased from $\mathrm{K}_{1}$ to $\mathrm{K}_{2}$. The maximum nut weight was recorded at $\mathrm{B}_{2}$ level of boron at $7^{\text {th }}$ month sage of nuts after application as 
evident from pooled result $(1825.50 \mathrm{~g})$.With further increase in potassium to $\mathrm{K}_{3}$ level the nut weight was significantly reduced. Potassium is not reported to cause any toxicity even at a still higher rate of application. As already mentioned, it is possible that potassium at the level is reducing the uptake of some other nutrient such as boron. Many of the functions of potassium and boron are overlapping and at high potassium level, the uptake of boron is often reduced (Mengel and Kirkby, 2001).

\section{Interaction effects of boron and potassium application on nut weight}

The results pertaining to boron-potassium interaction effects on nut weight are presented in Table 2 and Figures 3. The nut weight was the highest at $7^{\text {th }}$ month age of nuts after application. The pooled results revealed that among the treatments, $\mathrm{B}_{2} \mathrm{~K}_{2}(1948.50 \mathrm{~g})$ was the best and significant over all the treatment combinations followed by $\mathrm{B}_{2} \mathrm{~K}_{3}(1875.63 \mathrm{~g})$ and $\mathrm{B}_{1} \mathrm{~K}_{2}(1868.63 \mathrm{~g})$ and from $7^{\text {th }}$ month onwards, the nut weight had a continued decrease. The present findings are supported by those of Poduval et al., (1998), Jayalekshmi et al., (1988), Apshara et al., (2007) and Angela et al., (2008).The results suggested that for reaching the maximum nut weight, $\mathrm{B}_{2} \mathrm{~K}_{2}$ level should be recommended in coconut plantations under terai zone of West Bengal.

\section{References}

Ahmad, W., Niaz, A., Kanwal, S.R. and Rasheed, M.K. (2009). Role of boron in plant growth: A review. Journal of Agricultural Research, 47: 329-338.

Angela, K., Edmar, C., Angela, S. and Joao, B.V. (2008). Quality of coconut water in nature belonging to green dwarf fruit variety in different stages of development, in plantation on the northwest area of Parana, Brazil. Journal of Food, Agriculture and Environment, 6 (1):102-105.

Apshara, S.E., $\quad$ Arunachalam, V., Jayabose, C., and Kumaran, P. M. (2007). Evaluation of coconut hybrids for tender nut purpose. Indian Journal of Horticulture, 64 (3): 314-319.

Berger, K. C. and Truog, E. (1939). Boron determination in soils and plants. Ind. Eng. Chem, 11: 540-545.

Bray, R. H. and Kurtz, L.T. (1945). Determination of total, organic and available forms of phosphorus in soils. Soil Science, 59: 39-45.

De Silva, M.A.T. (1968). Recommended methods of fertilizer application for coconut palms. Ceylon Coconut Planters, 3:108-111.

Jackson, M. (1973). Soil chemical analysis. Prentice hall of India private limited, New Delhi.

Jackson, M. L. (1967). Soil Chemical Analysis. Prentice-Hall of India, New Delhi.

Jayalekshmi, A. C., Arumugham, S., Narayanan, C. and Mathew, A. G. (1988). Changes in chemical composition of coconut water during maturation. Oleagineux, 43: 409-414.

Mengel, K and Kirkby, E.A. (2001). Principles of Plant Nutrition. $5^{\text {th }}$ edition. Dordrecth: Kluwer Academic Publishers, pp: 849.

Mengel, K. (1985). Dynamics and availability of major nutrients in soils. Advances in Soil Science, 2: 65-115.

Moura, J.Z., Prado, R.M., Benvindo, R.N. and Chaves, A.L. (2013). Applying boron to coconut palm plants: effects on the soil, on the plant nutritional status and on productivity boron to coconut palm trees. Journal of Soil Science and Plant Nutrition, 13 (1): 79-85.

Muhr, G.R., Datta, N.P., Sankarasubramoney, H., Leley, V.K. and Dunabha, R.L. 
(1965). Soil testing in India. Second edition, USAID-Mission to India, New Delhi.

Nistane, N. G., Padhiar, B. V., Bhalerao, P. P., and Bhalerao, R. R. (2011). Influence of micronutrients on flowering, yield, and quality and leaf nutrient status of coconut cv. HYBRID D xT. Asian Journal of Horticulture, 6 (1): 89 - 91 .

Poduval, M., Abu Hasan, M. D. and Chattopadhyay, P. K. (1998). Evaluation of coconut cultivars for tender nut water for West Bengal. Indian Coconut Journal, 29 (1): 3 - 6.

Ranade-Malvi, U. (2011). Interaction of micronutrients with major nutrients with special reference to potassium. Karnataka Journal of Agricultural science, 24 (1): 106-109.

Reuter, D. J. and Robinson, J.B. (1997). Plant Analysis: An Interpretation manual $\left(2^{\text {nd }}\right.$ edition). CSIRO Publishing

Samet, H., Cikili, Y. and Dursun, S. (2015). The role of potassium in alleviating boron toxicity and combined effects on nutrient concentrates in pepper (Capsicum annuum L.). Bulgarian Journal of Agricultural Sciences, 21 (1): 64-70.

Singh, P. C., Gangwar, R. S. and Singh, V. K. (2012). Effect of micronutrients spray on fruit drop, fruit quality and yield of Aonla cv. Banarasi. Hort. Flora Research Spectrum, 1 (1):73-76.

Subbaiah, B.V. and Asija, G.L. (1956). A rapid procedure for the determination of available Nitrogen in soils. Current Science, 25: 256-260.

Venkitaswamy, R., Hameed Khan, H. and Palaniswami, C. (2011). Effect of graded levels of NPK on the reproductive characters and yield of hybrid coconut (COD X WCT). Tropical Agriculture, 86:13-20

Walkley, A. and Black, I.A. (1934). An examination of the different method for determining soil organic matter and a proposed modification of the chromic acid titration method. Journal of Soil Science, 37: 93 - 101.

\section{How to cite this article:}

Sathi Babu, N., P. S. Medda, Himadri Bhattacharjee, A. Kumar Sinha and Ghosh, A. 2021. Leaf Boron and Potassium and Nut Weight in Coconut (Cocos nucifera L.) as Affected by their Individual and Combined Applications in Terai Region of West Bengal. Int.J.Curr.Microbiol.App.Sci. 10(02): 919-927. doi: https://doi.org/10.20546/ijcmas.2021.1002.108 